\section{'Shenandoah' Pear}

Richard L. Bell ${ }^{1,3}$ and Tom van der $\mathbf{Z w e t}^{2}$
U.S. Department of Agriculture, Agricultural Research Service, Appalachian
Fruit Research Station, 2217 Wiltshire Road, Kearneysville, WV 25430-2771

Additional index words. Pyrus communis, cultivar, breeding, fire blight, Erwinia amylovora, disease resistance, host plant resistance, fruit quality, storage life

'Shenandoah' pear (Pyrus communis L.) is a new cultivar that combines spicy aromatic fruit flavor, long storage life, large fruit size, consistent yields, and moderate resistance to fire blight caused by the bacterium Erwinia amylovora (Burr.) Winsl. et al. (van der Zwet and Beer, 1999). All major cultivars of commercial importance as well as many of those available to home orchardists are susceptible to this devastating disease, which is endemic to most production regions of the northern hemisphere (van der Zwet and Beer, 1999). Long storage life, absence of core breakdown, and resistance to superficial scald are also economically important physiological traits. 'Shenandoah' was released by the U.S. Department of Agriculture and The Ohio State University in 2003 as a fresh market pear for commercial and home orchards.

\section{Origin}

'Shenandoah' is a seedling of 'Max Red Bartlett' and US56112-146 (Fig. 1), the cross made in 1977 by T. van der Zwet and R.C. Blake. The parentage is entirely of $P$. communis origin, and the original source of resistance is presumed to be the old American cultivar, Seckel, thought to be a parent of 'Barseck'. The original seedling, designated US78304-057, was selected in 1985 by R.L. Bell at the Appalachian Fruit Research Sta-

Received for publication 7 May 2008. Accepted for publication 24 July 2008.

We thank Dr. D.D. Miller, the administration, and staff of The Ohio State University's Ohio Agricultural Research and Development Center for their cooperative role. We recognize the contribution of R.C. Blake in planning the cross and Wayne Zook, Greg Brenneman, John Walter, Roger Lewis, and Daniel Bullock for providing technical assistance in the evaluations. We also thank Kenneth Eastwell, William Howell, and their staff at the National Research Support Project No. 5, Washington State University, for providing virus and phytoplasm testing.

Mention of a trademark, proprietary product, or vendor does not constitute a guarantee or warranty of the product by the U.S. Department of Agriculture and does not imply its approval to the exclusion of other products or vendors that also may be suitable.

${ }^{1}$ Research Horticulturist.

${ }^{2}$ Research Plant Pathologist, retired.

${ }^{3}$ To whom reprint requests should be addressed; e-mail richard.bell@ars.usda.gov tion (AFRS). The selection was further evaluated in a nonrandomized planting of six trees propagated on 'Bartlett' seedling rootstock at AFRS (Bell and van der Zwet, 1993) and in randomized, replicated plantings at AFRS (10 trees) and The Ohio State University-Ohio Agricultural Research and Development Center, Wooster, OH (10 trees), where all trees were propagated on 'Bartlett' seedling rootstock. It is also currently being tested by eight cooperators throughout the United States for performance under diverse climatic conditions. It was jointly released as a cultivar in 2003 by the U.S. Department of Agriculture and The Ohio State University. Budwood has tested negative for viruses and pear decline phytoplasma at the National Research Support Project No. 5 at Washington State University, Prosser, WA. The cultivar is named for the nearby Shenandoah River.

\section{Description}

Fruit traits. Fruit are oblong-ovatepyriform, ovate-pyriform, and obovateacute-pyriform (Zielinski, 1955), equivalent to the International Board for Plant Genetic Resources shape ratings of 3.2, 5.2, and 5.1, respectively (Thibault et al., 1983; Fig. 2), and moderately large, averaging $72 \mathrm{~mm}$ in diameter, 92 in length, and weighing $235 \mathrm{~g}$ (Table 1). Skin color at harvest is light green with $10 \%$ to $25 \%$ red blush. The skin turns yellow-green when ripe (Fig. 2). The finish is glossy. The skin surface is usually smooth but can sometimes be uneven. The crosssectional contour can vary from symmetrical to ribbed. The cavity is obtuse and occasionally acute. The basin is medium in depth and

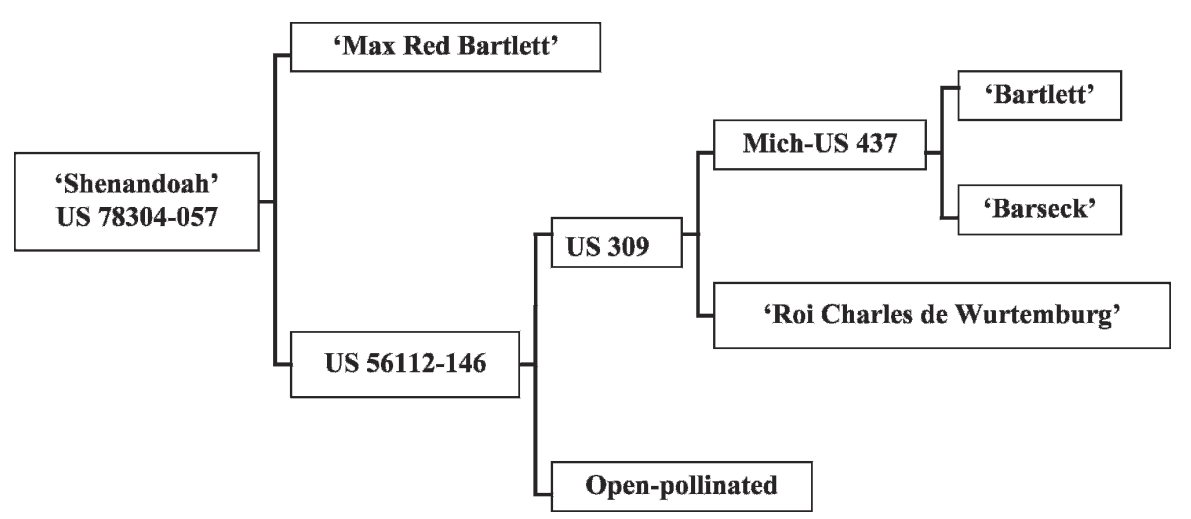

Fig. 1. Pedigree of 'Shenandoah'. sloping, and the calyx is persistent and convergent. There is usually some light calyx-end tan russet under conditions at AFRS, and lenticels are slightly conspicuous. The stem is medium to long $(\approx 25 \mathrm{~mm})$, of medium thickness $(\approx 3 \mathrm{~mm})$, upright, and usually curved. Flesh texture is moderately fine, juicy, and buttery. Flesh color is creamy white. Small grit cells occur primarily around the core and under the skin, similar to 'Bartlett' but with overall grit content and size less than 'Bartlett'. Core size is medium $(21 \mathrm{~mm})$, similar to 'Bartlett'. Harvest maturity has been estimated to occur $\approx 3$ weeks after 'Bartlett'. In air storage at $-1{ }^{\circ} \mathrm{C}$, fruit will store for as long as $111 \mathrm{~d}$ without superficial scald or internal breakdown. When harvested firm but optimally mature, the fruit will ripen without postharvest chilling, but 10 to $12 \mathrm{~d}$ at $20^{\circ} \mathrm{C}$ were required to reach flesh firmness acceptable for eating. The mean shelf life (number of days to soften to eating ripeness) varied from 5 to $10 \mathrm{~d}$ depending on harvest date. The flavor is sweet and aromatic, but acidity is also high at harvest and during the first 2 months after harvest, thereafter decreasing so that the overall character is subacid.

Tree traits. Trees are moderately vigorous on 'Bartlett' seedling rootstock and uprightspreading in growth habit, similar to 'Conference'. Full-bloom at AFRS is midseason, similar to 'Bartlett'. Cropping has been moderately precocious with first fruit set 3 years after planting (Table 2). Yield ratings beginning in the fourth year of growth after planting have been moderately high and greater than 'Bartlett'. In a test planting at AFRS on 'Bartlett' seedling rootstock, mean cumulative yield per tree 10 years after planting was $136.7 \mathrm{~kg}$ for 'Shenandoah' versus $59.8 \mathrm{~kg}$ for 'Bartlett' $(\mathrm{Pr}>\mathrm{F}=$ $0.0001)$. Secondary bloom is rare.

Fire blight resistance. Although not immune or highly resistant to fire blight shoot (Table 3) or blossom infections (Table 4), the severity of infections is less severe than those in 'Bartlett'.

\section{Availability}

Budwood of 'Shenandoah' is limited and trees are not available from either the U.S. 

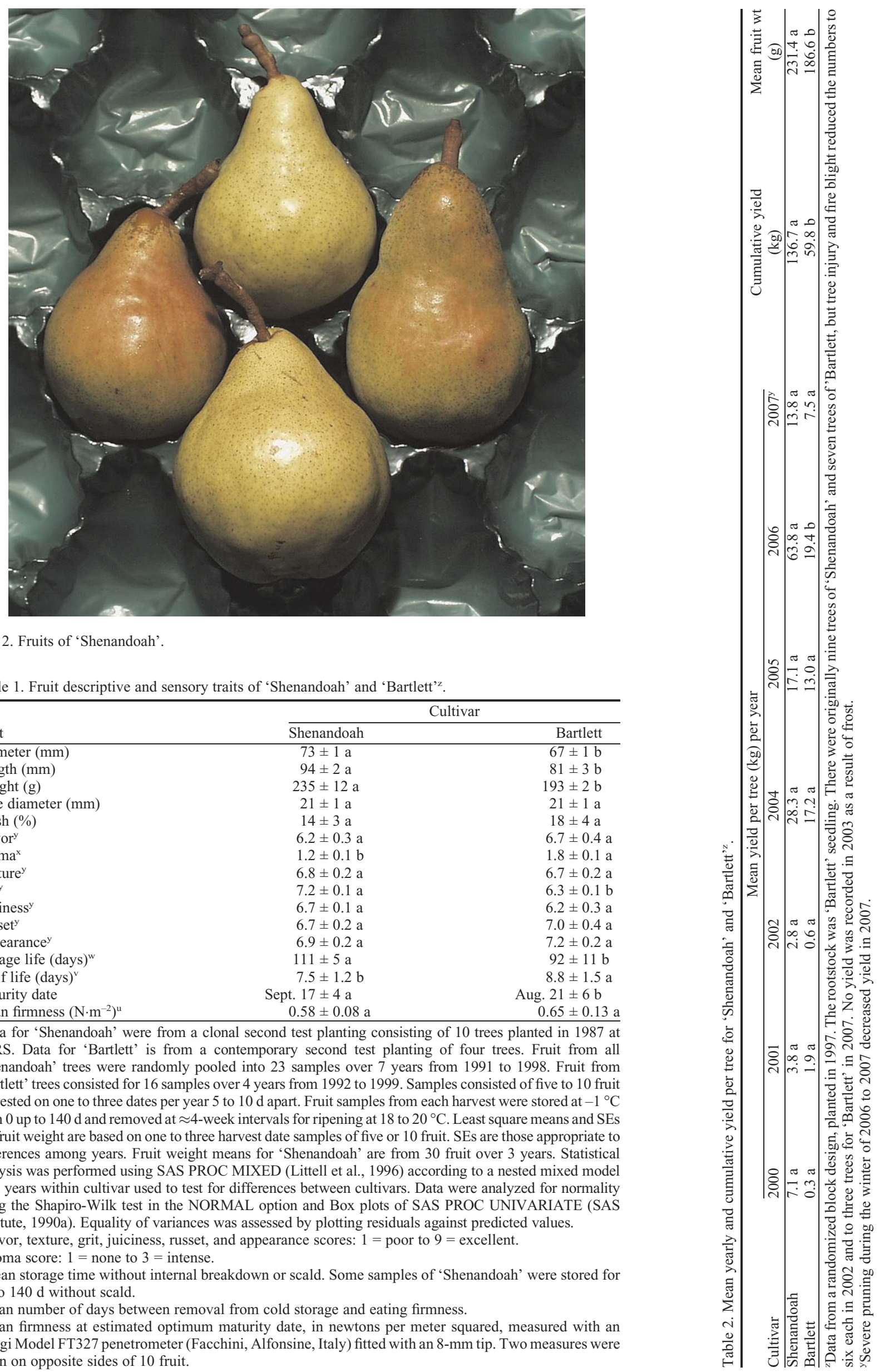

Table 1. Fruit descriptive and sensory traits of 'Shenandoah' and 'Bartlett'z.

\begin{tabular}{|c|c|c|}
\hline \multirow[b]{2}{*}{ Trait } & \multicolumn{2}{|c|}{ Cultivar } \\
\hline & Shenandoah & Bartlett \\
\hline Diameter (mm) & $73 \pm 1 \mathrm{a}$ & $67 \pm 1 \mathrm{~b}$ \\
\hline Length (mm) & $94 \pm 2 \mathrm{a}$ & $81 \pm 3 b$ \\
\hline Weight $(\mathrm{g})$ & $235 \pm 12 \mathrm{a}$ & $193 \pm 2 b$ \\
\hline Core diameter (mm) & $21 \pm 1 \mathrm{a}$ & $21 \pm 1 \mathrm{a}$ \\
\hline Blush (\%) & $14 \pm 3 \mathrm{a}$ & $18 \pm 4 \mathrm{a}$ \\
\hline Flavor $^{\mathrm{y}}$ & $6.2 \pm 0.3 \mathrm{a}$ & $6.7 \pm 0.4 \mathrm{a}$ \\
\hline Aroma $^{x}$ & $1.2 \pm 0.1 \mathrm{~b}$ & $1.8 \pm 0.1 \mathrm{a}$ \\
\hline Texture $^{\mathrm{y}}$ & $6.8 \pm 0.2 \mathrm{a}$ & $6.7 \pm 0.2 \mathrm{a}$ \\
\hline Grit $^{\mathrm{y}}$ & $7.2 \pm 0.1 \mathrm{a}$ & $6.3 \pm 0.1 \mathrm{~b}$ \\
\hline Juiciness ${ }^{\mathrm{y}}$ & $6.7 \pm 0.1 \mathrm{a}$ & $6.2 \pm 0.3 \mathrm{a}$ \\
\hline Russet $^{\mathrm{y}}$ & $6.7 \pm 0.2 \mathrm{a}$ & $7.0 \pm 0.4 \mathrm{a}$ \\
\hline Appearance ${ }^{y}$ & $6.9 \pm 0.2 \mathrm{a}$ & $7.2 \pm 0.2 \mathrm{a}$ \\
\hline Storage life (days) ${ }^{\mathrm{w}}$ & $111 \pm 5 \mathrm{a}$ & $92 \pm 11 b$ \\
\hline Shelf life (days) ${ }^{\mathrm{v}}$ & $7.5 \pm 1.2 \mathrm{~b}$ & $8.8 \pm 1.5 \mathrm{a}$ \\
\hline Maturity date & Sept. $17 \pm 4$ a & Aug. $21 \pm 6 b$ \\
\hline Mean firmness $\left(\mathrm{N} \cdot \mathrm{m}^{-2}\right)^{\mathrm{u}}$ & $0.58 \pm 0.08 \mathrm{a}$ & $0.65 \pm 0.13 \mathrm{a}$ \\
\hline
\end{tabular}

zData for 'Shenandoah' were from a clonal second test planting consisting of 10 trees planted in 1987 at AFRS. Data for 'Bartlett' is from a contemporary second test planting of four trees. Fruit from all 'Shenandoah' trees were randomly pooled into 23 samples over 7 years from 1991 to 1998. Fruit from 'Bartlett' trees consisted for 16 samples over 4 years from 1992 to 1999 . Samples consisted of five to 10 fruit harvested on one to three dates per year 5 to $10 \mathrm{~d}$ apart. Fruit samples from each harvest were stored at $-1^{\circ} \mathrm{C}$ from 0 up to $140 \mathrm{~d}$ and removed at $\approx 4$-week intervals for ripening at 18 to $20^{\circ} \mathrm{C}$. Least square means and SEs for fruit weight are based on one to three harvest date samples of five or 10 fruit. SEs are those appropriate to differences among years. Fruit weight means for 'Shenandoah' are from 30 fruit over 3 years. Statistical analysis was performed using SAS PROC MIXED (Littell et al., 1996) according to a nested mixed model with years within cultivar used to test for differences between cultivars. Data were analyzed for normality using the Shapiro-Wilk test in the NORMAL option and Box plots of SAS PROC UNIVARIATE (SAS Institute, 1990a). Equality of variances was assessed by plotting residuals against predicted values.

${ }^{\mathrm{y}}$ Flavor, texture, grit, juiciness, russet, and appearance scores: $1=$ poor to $9=$ excellent.

${ }^{\mathrm{x}}$ Aroma score: 1 = none to 3 = intense.

wMean storage time without internal breakdown or scald. Some samples of 'Shenandoah' were stored for up to $140 \mathrm{~d}$ without scald.

${ }^{\mathrm{v}}$ Mean number of days between removal from cold storage and eating firmness.

"Mean firmness at estimated optimum maturity date, in newtons per meter squared, measured with an Effegi Model FT327 penetrometer (Facchini, Alfonsine, Italy) fitted with an 8-mm tip. Two measures were taken on opposite sides of 10 fruit. 
Table 3. Response to epiphytotic and artificial fire blight infection of shoots of 'Shenandoah' and 'Bartlett'.

\begin{tabular}{|c|c|c|c|c|c|c|}
\hline \multirow[b]{3}{*}{ Cultivar } & \multirow{2}{*}{\multicolumn{2}{|c|}{ Epiphytotic infection ${ }^{z}$}} & \multicolumn{4}{|c|}{ Artificial inoculation $^{y}$} \\
\hline & & & \multirow{2}{*}{$\begin{array}{l}\text { Mean no. } \\
\text { of shoots }\end{array}$} & \multirow{2}{*}{$\begin{array}{l}\text { Infection } \\
\text { frequency }\end{array}$} & \multirow{2}{*}{$\begin{array}{l}\text { Percent lesion } \\
\text { length }^{\mathrm{x}}\end{array}$} & \multirow{2}{*}{$\begin{array}{l}\text { Percent infection } \\
\text { in old wood }\end{array}$} \\
\hline & No. trees & Mean score & & & & \\
\hline$\overline{\text { Bartlett }}$ & 15 & $2.3 \pm 0.5 \mathrm{a}$ & 17.50 & $0.89 \mathrm{a}$ & $107 \mathrm{a}$ & $67 \mathrm{a}$ \\
\hline Shenandoah & 15 & $7.3 \pm 0.4 b$ & 16.25 & $0.67 \mathrm{a}$ & $47 \mathrm{~b}$ & $15 \mathrm{~b}$ \\
\hline
\end{tabular}

${ }^{\mathrm{z}}$ Lowest, i.e., most severe, rating of epiphytotic (i.e., natural) infection according to van der Zwet et al. (1970) in which $1=$ dead and $10=$ no symptoms. Trees observed over a period of 8 to 10 years at the Appalachian Fruit Research Station. Mean separation between cultivars was according to Fisher's protected $t$ test following one-way analysis of variance performed with SAS PROC GLM (SAS Institute, 1990c). ' Inoculations performed with a single isolate (AFRS 554 in 2004) or mixtures of isolates (Ea273, E2002, and AFRS 581 in 1990 and 1992; Ea273, AFRS 581, and MO-E-9 in 1993) of E. amylovora at $5 \times 10^{-7}$ to $1 \times 10^{8} \mathrm{cfu} / \mathrm{mL}$, using a hypodermic syringe (Bell et al., 1996) in 1990, 1992, and 1993, and a scissorsdip method (Norelli et al.,1988) in 2004. Actively growing shoot tips were inoculated in late May or early June. Total shoot length, lesion length, and age of infected wood were measured after necrosis had stopped progressing. Final lesion length was divided by total shoot length to derive percent lesion length. All data were collected at the Appalachian Fruit Research Station.

${ }^{x}$ Percent lesion length $=($ lesion length/total shoot length $) \times 100$. Mean of 4 years data on percent of total number of inoculated shoots that developed lesions. Lesion length, percent lesion length, and arcsinetransformed percentage data were analyzed for normality using the Shapiro-Wilk test in the NORMAL option of SAS PROC UNIVARIATE (SAS Institute, 1990a). In most cases, the arcsine transformation did not improve normality. Therefore, percentage lesion length was analyzed without transformation, using SAS PROC GLM, with Type III sum of squares (SAS Institute, 1990c). A factorial treatment design with years and cultivars as fixed effects was used, least square means and SEs for the main effects were computed, and differences between the two cultivars tested by Fisher's protected $t$ test.

wooled data for the 4 years were tested using the $\chi^{2}$ test of SAS PROC FREQ (SAS Institute, 1990b).

Table 4. Frequency and severity of artificial fire blight infections in blossoms of 'Shenandoah' and 'Bartlett'z.

\begin{tabular}{lcccc}
\hline Cultivar & Year & $\begin{array}{c}\text { Percent infected } \\
\text { blossoms }^{\mathrm{y}}\end{array}$ & $\begin{array}{c}\text { Percent infected } \\
\text { spurs/wood }^{\mathrm{y}}\end{array}$ & $\begin{array}{c}\text { Lesion length } \\
(\mathrm{mm})^{\mathrm{x}}\end{array}$ \\
\hline Bartlett & 1998 & 92 & $64 \mathrm{a}$ & $230 \mathrm{a}$ \\
Shenandoah & 1998 & 84 & $13 \mathrm{~b}$ & $160 \mathrm{a}$ \\
Bartlett & 2004 & 95 & $98 \mathrm{a}$ & $664 \mathrm{a}$ \\
Shenandoah & 2004 & 98 & $85 \mathrm{~b}$ & $238 \mathrm{~b}$ \\
\hline
\end{tabular}

${ }^{\mathrm{z}}$ In 1998, five recently opened blossoms on each of 20 clusters were spray inoculated with an suspension of $E$. amylovora isolates AFRS 554 and AFRS 581 at equal concentrations of $5 \times 10^{7} \mathrm{cfu} / \mathrm{m}$, whereas in 2004 , four blossoms on each of 30 clusters were individually inoculated by pipetting a $25-\mu \mathrm{L}$ drop of AFRS 554 inoculum at a concentration of $3 \times 10^{7} \mathrm{cfu} / \mathrm{mL}$ into the hypanthia. Percent infection was recorded $7 \mathrm{~d}$ after infection in both years, and infection of spurs or older limbs was recorded after 8 weeks, when infection stopped progressing.

y Percentage infected blossoms and percentage infection of spurs or older wood was analyzed within each year using the $\chi^{2}$ test of SAS PROC FREQ (SAS Institute, 1990b).

${ }^{x}$ Lesion length was analyzed without transformation using SAS PROC GLM using Type III sum of squares with mean separation by Fisher's protected $t$ test (SAS Institute, 1990c).

Department of Agriculture or The Ohio State

University. Pathogen-free certified budwood

will be available to nurseries and researchers

from NRSP No. 5 (http://nrsp5.prosser. gov/cor), where it will be available for research, including development and commercialization of new cultivars. 'Shenandoah' is not patented. However, when this germplasm contributes to the development of a new cultivar, selection, mutant clone, or other germplasm, it is requested that appropriate recognition be given to the source. Limited amounts of noncertified budwood will be available from Richard Leslie Bell.

\section{Literature Cited}

Bell, R.L. and T. van der Zwet. 1993. New fire blight resistant advanced selections from the USDA pear breeding program. Acta Hort. 338:415-419.

Bell, R.L., T. van der Zwet, R.C. Blake, C.K. Chandler, and J.C. Scheerens. 1996. 'Potomac' pear. HortScience 31:884-886.

Littell, R.C., G.A. Milliken, W.W. Stroup, and R.D. Wolfinger. 1996. SAS ${ }^{\circledR}$ system for mixed models.. SAS Institute, Cary, NC.

Norelli, J.L., H.S. Aldwinckle, and S.V. Beer. 1988. Virulence of Erwinia amylovora strains to Malus sp. Novole plants grown in vitro and in the greenhouse. Phytopathology. 78: 1292-1297.

SAS Institute, Inc. 1990a. SAS procedures guide, Version 6. 3rd Ed. SAS Institute, Cary, NC.

SAS Institute, Inc. 1990b. SAS/STAT user's guide, Version 6. 4th Ed., Vol. 1. SAS Institute, Cary, NC.

SAS Institute, Inc. 1990c. SAS/STAT user's guide, Version 6. 4th Ed., Vol. 2. SAS Institute, Cary, NC.

Thibault, B., R. Watkins, and R.A. Smith (eds.). 1983. Descriptor list for pears (Pyrus). Intl. Board Plant Genet. Resources, Rome, Italy.

van der Zwet, T. and S.V. Beer. 1999. Fire blight-Its nature, prevention, and control: A practical guide to integrated disease management. U.S. Department of Agriculture, Agriculture Information Bulletin No. 631.

van der Zwet, T., W.A. Oitto, and H.J. Brooks. 1970. Scoring system for rating severity of fire blight in pear. Plant Dis. Rptr. 54:835-839.

In addition, budwood has be deposited in the National Plant Germplasm System at the National Clonal Germplasm Repository, Corvallis, OR (http://ars-grin.
Zielinski, Q.B. 1955. Modern systematic pomology. W.C. Brown, Dubuque, IA. 